\section{Greater Pittsburgh Section Holds Fall Meeting}

The Greater Pittsburgh Section of the Materials Research Society celebrated its second anniversary on October 6, 1992 at the Carnegie Museum. Pamela Vandiver of The Smithsonian Institution was the guest speaker.

More than 100 people attended the meeting, including representatives from Carnegie Mellon, the University of Pittsburgh, PPG Industries, Westinghouse, Kennametal, Alcoa, R.J. Lee, Kurt Lesker Co., MRS headquarters, and members of the Greater Pittsburgh Section of the American Ceramic Society.

Vandiver's talk on "The Ancient Technology of Ceramic Materials" described the development of ceramics as learned from archeological findings. She spoke on the characterization of ancient materials, and other "special" materials such as Tiffany Glass, detailing how she had used modern electron microscopy and other modern materials science techniques to understand the processes used to fabricate these materials. She noted that many of these older processes have evolved into the sophisticated processes used today for producing advanced ceramic materials. Describing her laboratory and field work over the past twelve years, Vandiver displayed relics from her collection, and materials such as the ceramic sickle made in her laboratory at the Smithsonian. A questionand-answer session followed the talk.

Also present at the meeting were the Section's current officers: S. Shankar, Prashant Kumta, and Michael McHenry (Carnegie Mellon University); Pradeep Phule (University of Pittsburgh); and John Basil (PPG Industries).

All those attending the meeting were invited to contribute to the future development of the Section and to help plan forthcoming events. The Section plans to hold its next meeting in spring 1993, with plans for a symposium in summer 1993. For information, call P.N. Kumta (412) 2688739, P.P. Phule (412) 624-9736, S. Shankar (412) 268-5649, or M.E. McHenry (412) 2682703.

\section{COMING IN JANUARY}

Guest editors Y. Bruynseraede (Katholieke Universiteit, Leuven, Belgium) and Ivan Schuller (University of California-San Diego) present the second of a two-part feature on Quantitative Analysis of Thin Films.

\section{Nominations Due for 1993 MRS Spring Meeting Graduate Student Awards}

Nominations for MRS Graduate Student Awards to be presented at the 1993 MRS Spring Meeting, April 12-April 16 in San Francisco, California are due at MRS Headquarters by January 15, 1993.

Winners will be selected in two steps. First, a group of finalists will be identified on the basis of the award applications. Then finalists, who will be notified six weeks before the meeting, will be required to give a 10-minute talk based on their symposium papers at a special session during the 1993 MRS Spring Meeting. Winners will be announced at the Spring Meeting Plenary Session.

The registration fee for the 1993 Spring Meeting will be paid for all finalists, entitling them to MRS membership for the remainder of the 1993 calendar year. Award winners will receive, in addition, a $\$ 250$ cash prize and a plaque.

\section{Eligibility}

To qualify for an MRS Graduate Student Award for the 1993 MRS Spring Meeting, applicants must be registered graduate students whose thesis closely relates to one of the symposium topics for this meeting. Applicants must be authors or co-authors of symposium papers, but need not be the presenters. MRS membership is not required, but the students must attend the 1993 MRS Spring Meeting. Students are not eligible if they receive their degrees more than four months before the meeting.

\section{To Apply}

For more information and application forms, please contact:

Materials Research Society

1993 MRS Spring Meeting

Graduate Student Awards

9800 McKnight Road

Pittsburgh, PA 15237

Phone (412) 367-3003

Fax (412) 367-4373

\section{Advertisers in This Issue:}

\section{Page No.}

\begin{tabular}{lr}
\hline BOMEM Inc. & 17 \\
\hline Cree Research inc. & 32 \\
\hline CSIRO & 15 \\
\hline Digital Instruments & inside back cover \\
\hline Elsevier Science Publishers & 48,50 \\
\hline Fei Company & 6 \\
\hline High Voltage Engineering & inside front cover \\
\hline \multicolumn{2}{|l}{ Europa B.V. } \\
\hline Instruments SAJJOBIN YVON & 9 \\
\hline JEOL USA, Inc. & 3 \\
\hline MDC Vacuum Products Corp. & 19 \\
\hline
\end{tabular}

Page No.

\begin{tabular}{lr}
\hline National Electrostatics Corp. & 14 \\
\hline Perkin Elmer & 22 \\
\hline $\begin{array}{lr}\text { Philips Electronic } \\
\text { Instruments Inc. (PEI) }\end{array}$ & 4 \\
\hline \begin{tabular}{lr} 
Pure Tech Inc. \\
\hline $\begin{array}{l}\text { Specmark Information } \\
\text { Engineering Inc. }\end{array}$ & back cover \\
\hline
\end{tabular}
\end{tabular}

VCH Publishers 23

Virginia Semiconductor, Inc. 10

Voltaix, Inc.

12

Carl Zeiss, Inc. 13
For free information about the products and services offered in this issue, fill out and mail the Reader Service Card, or FAX it to (312) 922-3165. 